\title{
Study of on-farm pre and post-natal feeding practices of Red Chittagong Cattle
}

\author{
N.G. Das, N.R. Sarker*, K.S. Huque and M.A.I. Talukdar \\ Bangladesh Livestock Research Institute, Savar, Dhaka - 1341
}

\begin{abstract}
The study was conducted with the objective to investigate prenatal and postnatal performances of Red Chittagong Cattle (RCC) cows in subsistence feeding and nutrition compared to those in improved feeding system. Twenty RCC cows with average initial live weight of $204.6( \pm 29) \mathrm{kg}$ at their $2 \mathrm{nd}$ or 3rd parity and at about seven months of pregnancy were divided into two equal groups and assigned to two dietary treatments: one group was fed as per farmers' choice, while another was fed 25\% higher metabolizable energy (ME) and crude protein (CP) than requirements through concentrates, according to ARC (2009). Cows in farmers' diet during last 50 days of pregnancy fed lower ME and CP (42.4 MJ and $445 \mathrm{~g}$, respectively) than their daily requirements (43.5 MJ and $519 \mathrm{~g}$, respectively), resulted in lower birth weight of calves compared to improved feeding (13.36 and $15.12 \mathrm{~kg}$, respectively) where daily ME and $\mathrm{CP}$ intake was $57.77 \mathrm{MJ}$ and $603 \mathrm{~g}$. In first 60 days of lactation, cows under farmers' diet fed required amount of $\mathrm{ME}$ and $\mathrm{CP}$ (44.83 MJ and 471g, respectively) compared to requirement (42 MJ and 388g, respectively). However, cows in improved diet fed 1.28 and 1.42 times higher ME and CP (52.92 MJ and $563 \mathrm{~g}$ ) than requirements, and produced higher milk (1.97 and $2.50 \mathrm{~L} / \mathrm{d} ; \mathrm{P}<0.05)$ and daily gain (122 and $274 \mathrm{~g} / \mathrm{d} ; \mathrm{P}<0.01$ ), compared to that of farmers' diet cows. Therefore, it was concluded that diet of RCC cows in late pregnancy may be supplemented with $\mathrm{CP}$ in order to produce higher birth weight of calves. In case of lactating cows, a cost effective supplementation of concentrate mixture for increasing milk production and daily gain may be investigated by doing further research.
\end{abstract}

(Key words: Red Chittagong Cattle, nutrient requirement, daily gain and milk production, on-farm feeding and nutrition)

\section{Introduction}

The Red Chittagong Cattle (RCC) is considered as one of the important indigenous cattle genetic resources of Bangladesh. It is reared mainly by poor farmers in its habitats at Chittagong regions of the country and used for dairy, beef and draught purpose simultaneously. This cattle variety is unique due to its reddish coat, horns, hoofs, muffles, eye lashes and tail switch. Live weight, of adult male and female $\mathrm{RCC}$ is about 436 and $192 \mathrm{~kg}$, respectively (Mostari et al., 2007). The lactation length of RCC under farm condition was reported as
238 days, and daily milk production as $2.24 \mathrm{~L}$ (Mostari et al., 2007) which is significantly higher than local cows $(1.63 \mathrm{~L} / \mathrm{d}$; Bhuiyan and Faruque, 1993). Compared to crossbred cows, milk fat content was also found higher in RCC milk (about $6 \%$; Akhter et al., 2004). In addition, owing to small body size, high disease resistance, and capacity to survive in poor feeding and management conditions, this cattle variety was stated to be suitable for poor smallholder farmers of the country (Islam, 2010).

However, study on feeding and nutrition status of pregnant RCC cows at subsistence

*Corresponding author: sarkernr62@yahoo.com

Bang. J. Livs. Res. Special Vol. 21-25, 2018: P. 159-167, ISSN 1022-3851 
farming system affecting their productive performance is limited. Due to qualitative and quantitative shortage of feeds and fodder in Bangladesh (Huque and Sarker, 2014), feeding of rice straw to RCC as basal diet with little concentrate supplementation - a common feeding practice of RCC farmersmay not be sufficient to meet the daily nutrient requirements either for maintenance or production. Dietary deficiency of nutrients, especially energy and protein, can cause poor productive and reproductive performance of RCC. Many important implications of prenatal nutrition of cows with their productive and reproductive performances has been noted (Ken Ziegler, 2009). Therefore, the study was undertaken with the objective to investigate prenatal and postnatal performances of RCC cows in subsistence feeding and nutrition compared to those in improved feeding.

\section{Materials and Methods}

Twenty RCC cows of 7 months pregnancy within 2 or 3 parities were selected at Latabania, Dolir Gopat, Fokirkhil and Notunhat villages under Satkania upazila of Chattogram district, and randomly assigned into two dietary groups, starting from March 15 to August 15, 2013. One group ( $\left.T_{1}\right)$ was fed according to farmers' choice, while another group $\left(\mathrm{T}_{2}\right)$ received $25 \%$ above the requirements of metabolizable energy (ME) and crude protein (CP) according to ARC (2009), which was maintained through supplementing improved concentrate mixtures. Daily supply of roughages and their refusals were weighed and recorded. In farmers' choice group, quantitative daily supply of different concentrate ingredients was recorded. In improved feeding group, calculating nutrient deficiency of diet, a mixture of conventional concentrate ingredients was produced and its daily allowance was calculated so that intake of $\mathrm{ME}$ and $\mathrm{CP}$ was maintained at $25 \%$ above the actual requirements according to ARC (2009). This mixture of concentrate ingredients and daily allowances was updated fortnightly according to live weight (LW) of cows and requirements. During lactation, in addition to maintenance requirement, nutrient requirements for producing $3 \mathrm{~L}$ milk daily were considered in formulating concentrate mixtures. A portable digital balance was used to take live weight of cows fortnightly. Nutrient intake of cows from roughage was calculated by subtracting refusal nutrients from fresh roughage nutrients supplied. Nutrient intake from concentrate was calculated by multiplying the amount consumed and their chemical composition; no refusals were found in case of concentrates. The chemical composition of conventional feedstuffs (roughage and concentrate) and average ingredient composition of concentrate mixtures of both farmers' choice diet and improved diet are presented in Table 1 and 2, respectively. Fresh and representative samples of feedstuffs used by different farmers were collected, kept in properly labeled airtight polyethine bags, and stored in deep freeze $\left(-20{ }^{\circ} \mathrm{C}\right)$ until analysis. At the same time, representative samples of concentrate ingredients used according to either farmers' choice or improved feeding were sampled, collected in airtight polyethine bags and stored in deep freeze $\left(-20^{\circ} \mathrm{C}\right)$ until analysis. At the end of trial, samples of different feedstuffs were thawed at room temperature, 
pooled, mixed thoroughly and representative samples were produced. A portion of that was used to determine dry matter content by drying in an oven at $60^{\circ} \mathrm{C}$ for $48 \mathrm{~h}$, while another portion was dried, milled by passing through $1 \mathrm{~mm}$ sieve of Willey mill and sent to laboratory for determining chemical composition at Animal Nutrition Laboratory of Bangladesh Livestock Research Institute, Savar, Dhaka, following the method of AOAC (2003). Data on LW gain of cows, birth weight of calves; milk yield and post-partum days were recorded and analyzed for Paired-Samples $\mathrm{T}$ Test to compare means using SPSS (11.5).

Table1. Chemical composition of roughage and concentrates fed to RCC cows

\begin{tabular}{lcccc}
\hline Feedstuffs & DM & OM & CP & ME* \\
\cline { 2 - 5 } & \% fresh & \multicolumn{2}{c}{$\%$ DM } & MJ/kg DM \\
\hline Rice straw & 91.88 & 85.35 & 3.85 & 5.38 \\
Local grass & 23.55 & 84.44 & 9.09 & 7.29 \\
Rice polish (coarse) & 91.28 & 90.77 & 7.70 & 7.72 \\
Rice broken & 88.2 & 96.52 & 8.50 & 13.6 \\
Brinjal & 7.62 & 98.86 & 17.77 & - \\
Bean (green) & 14.36 & 72.96 & 14.91 & - \\
Bean pod (dry and broken) & 85.81 & 97.78 & 7.72 & - \\
Cluster of bean stem & 14.04 & 88.3 & 44.75 & - \\
Groundnut haulm & 27.07 & 82.05 & 16.11 & - \\
Concentrate ingredients & & & & \\
Wheat bran & 90.16 & 92.8 & 16.21 & 8.3 \\
Rice polish (fine) & 91.19 & 89.96 & 14.51 & 7.87 \\
Maize flour & 89.5 & 98.5 & 8.20 & 12 \\
Mustard oil cake & 91.79 & 89.3 & 31.50 & 20.58 \\
Soybean meal & 90.71 & 93.5 & 44.88 & 15 \\
\hline
\end{tabular}

RCC, Red Chittagong Cattle; DM, dry matter; OM, organic matter; CP crude protein; ME, metabolizable energy; MJ, megajoule; *Calculated as per Kearl (1982).

Table 2. Average ingredient composition of concentrate mixtures (\% fresh)

\begin{tabular}{|c|c|c|}
\hline \multirow[t]{2}{*}{ Name of ingredients $(\%$ fresh $)$} & \multicolumn{2}{|c|}{ Dietary groups } \\
\hline & Farmers' choice $\left(\mathrm{T}_{1}\right)$ & Improved feeding $\left(\mathrm{T}_{2}\right)$ \\
\hline Rice broken & $11.6( \pm 8.7)$ & - \\
\hline Rice polish & $85.1( \pm 10.8)$ & $20.6( \pm 14)$ \\
\hline Wheat bran & - & $24.7( \pm 11.1)$ \\
\hline Soybean meal & - & $20.0( \pm 7.5)$ \\
\hline Mustard oil cake (MOC) & - & $19.1( \pm 6.3)$ \\
\hline Maize flower & - & $13.3( \pm 11.5)$ \\
\hline $\mathrm{DCP}$ & - & 1.2 \\
\hline Common salt & $3.3( \pm 2.2)$ & 1.0 \\
\hline Total & 100.0 & 100.0 \\
\hline
\end{tabular}

Values within parenthesis represent standard deviations of means. 


\section{Results and Discussion}

\section{Nutrient intake of pregnant RCC cows (7 months onward)}

Prenatal requirement and intake of nutrients of cows during study period are given in Table 3 . There was no significant difference $(\mathrm{P}>0.05)$ between treatment groups in respect of average LW (221 and $219 \mathrm{~kg}$, respectively), metabolic LW (57.2 and $56.9 \mathrm{~kg}$, respectively) and feeding periods $(50$ and $56 \mathrm{~d}$, respectively). Similarly, daily requirements of $\mathrm{ME}$ and $\mathrm{CP}$ did not differ significantly
$(\mathrm{P}>0.05)$. Total DM intake (5.20 and $5.82 \mathrm{~kg}$, respectively), resulted from DM intake from roughage (4.37 and $4.61 \mathrm{~kg} / \mathrm{d}$, respectively; $\mathrm{P}>0.05$ ) and concentrate of dietary groups $(0.83$ and $1.20 \mathrm{~kg} / \mathrm{d}$, respectively; $\mathrm{P}>0.05)$, did not differ significantly $(\mathrm{P}>0.05)$; it represented 2.38 and 2.69 per cent of LW of cows. However, total $\mathrm{ME}$ and $\mathrm{CP}$ intake (42.44 and $57.77 \mathrm{MJ} / \mathrm{d} ; 445$ and $603 \mathrm{~g} / \mathrm{d}$, respectively) differed significantly $(\mathrm{P}<0.05)$ due to the significantly different $\mathrm{ME}$ and $\mathrm{CP}$ intake $(\mathrm{P}<0.05)$ from concentrates $(13.43$ and $27.84 \mathrm{MJ} / \mathrm{d} ; 134$ and $279 \mathrm{~g} / \mathrm{d}$, respectively);

Table 3. Nutrient intake of pregnant RCC cows (7-9 months)

\begin{tabular}{|c|c|c|c|c|}
\hline \multirow{2}{*}{ Parameters } & \multicolumn{2}{|c|}{ Treatments } & \multirow{2}{*}{ SEM } & \multirow{2}{*}{$\mathrm{P}$ values } \\
\hline & $\mathrm{T}_{1}$ & $\mathrm{~T}_{2}$ & & \\
\hline Average LWduring trial $(\mathrm{kg})$ & 221 & 219 & 17.00 & 0.945 \\
\hline Metabolic LW $(\mathrm{kg})$ & 57.2 & 56.9 & 3.30 & 0.944 \\
\hline Prenatal feeding period (d) & 50 & 56 & 8.03 & 0.471 \\
\hline \multicolumn{5}{|l|}{ Nutrient requirements } \\
\hline $\operatorname{ME}(\mathrm{MJ} / \mathrm{d})$ & 43.5 & 43.9 & 2.60 & 0.878 \\
\hline $\mathrm{CP}(\mathrm{g} / \mathrm{d})$ & 519 & 521 & 33.61 & 0.975 \\
\hline \multicolumn{5}{|l|}{ DM intake } \\
\hline Roughage (kg/d) & 4.37 & 4.61 & 0.25 & 0.358 \\
\hline Concentrate $(\mathrm{kg} / \mathrm{d})$ & 0.83 & 1.20 & 0.17 & 0.072 \\
\hline Total $(\mathrm{kg} / \mathrm{d})$ & 5.20 & 5.82 & 0.21 & 0.057 \\
\hline$\% \mathrm{LW}$ & 2.38 & 2.69 & 0.16 & 0.094 \\
\hline $\mathrm{g} / \mathrm{kgW}^{0.75} / \mathrm{d}$ & 91.4 & 103.2 & 4.70 & 0.043 \\
\hline \multicolumn{5}{|l|}{ ME intake } \\
\hline Roughage (MJ/d) & 29.01 & 29.93 & 1.37 & 0.525 \\
\hline Concentrate $(\mathrm{MJ} / \mathrm{d})$ & 13.43 & 27.84 & 3.51 & 0.005 \\
\hline Total $(\mathrm{MJ} / \mathrm{d})$ & 42.44 & 57.77 & 3.06 & 0.002 \\
\hline $\mathrm{MJ} / \mathrm{kgW}^{0.75} / \mathrm{d}$ & 0.75 & 1.02 & 0.03 & $<0.001$ \\
\hline Intake: requirement & 0.98 & 1.33 & 0.07 & 0.003 \\
\hline \multicolumn{5}{|l|}{ CP intake } \\
\hline Roughage (g/d) & 311 & 325 & 14.28 & 0.371 \\
\hline Concentrate $(\mathrm{g} / \mathrm{d})$ & 134 & 279 & 34.6 & 0.004 \\
\hline Total $(g / d)$ & 445 & 603 & 29.9 & 0.001 \\
\hline $\mathrm{g} / \mathrm{kgW}^{0.75} / \mathrm{d}$ & 7.83 & 10.68 & 0.38 & $<0.001$ \\
\hline Intake: requirement & 0.86 & 1.17 & 0.07 & 0.006 \\
\hline
\end{tabular}

RCC, Red Chittagong Cattle; LW, live weight; DM, dry matter; ME, metabolizable energy; CP, crude protein; $\mathrm{T}_{1}$, cows fed according to farmers' choice; $\mathrm{T}_{2}$, cows fed concentrate supplements to supply $25 \%$ more ME and CP than requirement (ARC, 2009); SEM, standard error of mean; $\mathrm{P}>0.05$, not significant. 
similar intake of ME (29.01 and $29.93 \mathrm{MJ} / \mathrm{d}$, respectively) and $\mathrm{CP}$ (311 and $325 \mathrm{~g} / \mathrm{d}$, respectively) from roughage sources $(\mathrm{P}>0.05)$ were found. In terms of metabolic $\mathrm{LW}$, both $\mathrm{ME}$ and $\mathrm{CP}$ intake in improved feeding group $(1.02 \mathrm{MJ} / \mathrm{kgW} 0.75 / \mathrm{d}$ and $10.86 \mathrm{~g} / \mathrm{kgW} 0.75 / \mathrm{d}$, respectively) was significantly higher $(\mathrm{P}<0.05)$ than farmers' choice group $(0.75 \mathrm{MJ} / \mathrm{kgW} 0.75 / \mathrm{d}$ and 7.83 $\mathrm{g} / \mathrm{kgW} 0.75 / \mathrm{d}$, respectively). The resultant intake of ME and $\mathrm{CP}$ was lower than requirement of cows $(0.98$ and 0.86 parts of requirement) in formers' choice diet, whereas in improved feeding group, it represented 1.33 and 1.17 times of requirements. The relationship between LW gain of cows with ME or $\mathrm{CP}$ intake, irrespective of feeding systems, is presented in Figure 1. A strong significant correlation existed $(\mathrm{n}=16, \mathrm{r}=$ between ME intake and LW gain of cows $\{$ MJ ME intake $=0.046 \times$ LW gain (g) $+24.34 ; \mathrm{n}, 16 ; \mathrm{r}, 0.853 ; \mathrm{P}<0.0005\}$. Relationship regarding CP intake and LW gain was also strongly significant $\{\mathrm{CP}$ intake $(\mathrm{g})=0.483 \times \mathrm{LW}$ gain $(\mathrm{g})+252.4 ; \mathrm{n}, 16 ; \mathrm{r}$, $0.884 ; \mathrm{P}<0.0005\}$.

From these correlations, although sample size is very small, daily maintenance requirements of $\mathrm{ME}$ and $\mathrm{CP}$ of the experimental cows stood at $24 \mathrm{MJ} / \mathrm{d}$ and 252 $\mathrm{g} / \mathrm{d}$. Data on nutrient requirements of indigenous cattle at metabolic level is scarce; however, Huque et. al. (2005) reviewed that the daily maintenance requirement of $\mathrm{ME}$ and $\mathrm{CP}$ for native bull of 171 and $153 \mathrm{~kg}$ live weight were $19.82 \mathrm{MJ}$ and $111 \mathrm{~g}$, respectively. Differences in sex, stage of pregnancy and LW might be the cause of higher maintenance requirement of the cows.

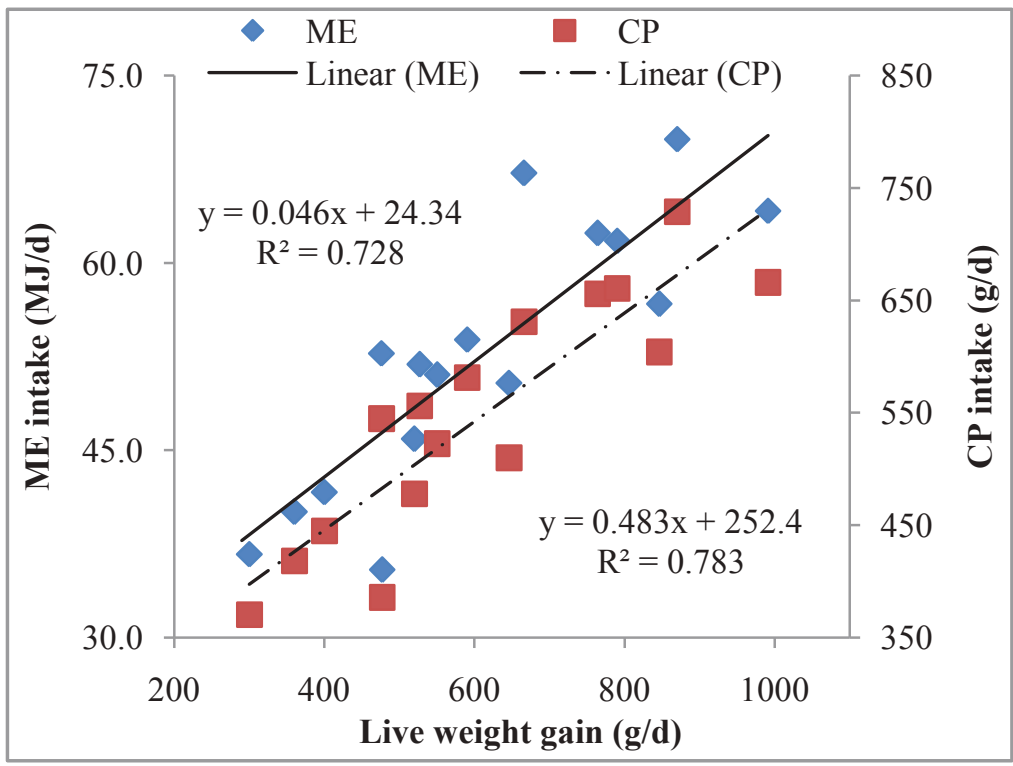

Figure 1. Relationship between live weight gain of pregnant RCC cows and their $\mathrm{ME}$ and $\mathrm{CP}$ intake

\section{Effects of improved feeding on live weight change of cows and birth weight of calves}

The effects of feeding on LW change of cows and birth weight of calves are presented in Table 4. The initial (209 and $200 \mathrm{~kg}$, respectively) and final LW of cows (232 and $239 \mathrm{~kg}$, respectively) was similar between dietary groups $(\mathrm{P}>0.05)$. Although LW gain of cows in improved feed feeding $(681 \mathrm{~g} / \mathrm{d})$ was numerically higher than that in farmers' choice feeding $(479 \mathrm{~g} / \mathrm{d})$, the values did not differ significantly $(\mathrm{P}>0.05)$. However, birth weight of calves, irrespective of sex, were found to increase significantly (13.36 to 
$15.12 \mathrm{~kg} ; \mathrm{P}<0.05)$ due to improved feeding practices.

In this study, difference in LW gain and birth weight of calves between dietary groups was $203 \mathrm{~g} / \mathrm{d}$ and $1.76 \mathrm{~kg}$, resulted from increased intake of ME and CP by $15.33 \mathrm{MJ}$ and $158 \mathrm{~g}$, respectively. Asaduzzaman, et. al. (2012) reported $161 \mathrm{~g} / \mathrm{d}$ gain of pregnant RCC cows and $10.95 \mathrm{~kg}$ of calf birth weight by 90 days prenatal feeding of $27.49 \mathrm{MJ} / \mathrm{d}$ ME and $279 \mathrm{~g} / \mathrm{d}$ CP from conventional feeds. Difference in nutrient intake and length of prenatal feeding period might be the cause of this variation. higher total DM intake (5.43 and $5.99 \mathrm{~kg} / \mathrm{d}$; $\mathrm{P}<0.01)$. Total DM intake in terms of per cent live weight was similar $(2.76$ and $3.10 \mathrm{~kg}$, respectively; $\mathrm{P}>0.05)$, but it was different when expressed as per kg metabolic LW (103 and $116 \mathrm{~g} / \mathrm{d}$, respectively; $\mathrm{P}<0.05$ ). Similarly, daily ME and $\mathrm{CP}$ intake of dietary groups from roughage was similar (36.43 and 35.75 MJ, and 385 and $377 \mathrm{~g}$, respectively; $\mathrm{P}>0.05$ ), but that from concentrate was significantly higher in improved feeding group (8.41 and $17.17 \mathrm{MJ}$, and 86 and $186 \mathrm{~g}$, respectively; $\mathrm{P}<0.010$ ) which resulted in significantly higher total $\mathrm{ME}$ and $\mathrm{CP}$ intake (44.83 and $52.92 \mathrm{MJ}$, and 471 and $563 \mathrm{~g}$,

Table 4. Live weight gain of RCC cows and birth weight of calves

\begin{tabular}{lrrrr}
\hline \multirow{2}{*}{ Parameters } & \multicolumn{2}{c}{ Treatments } & \multirow{2}{*}{ SEM } & \multirow{2}{*}{ P values } \\
\cline { 2 - 3 } & $\mathrm{T}_{1}$ & $\mathrm{~T}_{2}$ & & \\
\hline Initial live weight $(\mathrm{kg})$ & 209 & 200 & 17.86 & 0.637 \\
Final live weight $(\mathrm{kg})$ & 232 & 239 & 16.90 & 0.713 \\
Weight gain of cows (g/day) & 479 & 681 & 85.84 & 0.051 \\
Birth weight of calves (kg) & 13.36 & 15.12 & 0.75 & 0.044 \\
\hline
\end{tabular}

RCC, Red Chittagong Cattle; $\mathrm{T}_{1}$, cows fed according to farmers' choice; $\mathrm{T}_{2}$, cows fed concentrate supplements to supply $25 \%$ more ME and CP than requirement (ARC, 2009); SEM, standard error of mean; $\mathrm{P}>0.05$, not significant.

\section{Nutrient intake of early lactating RCC cows}

Postnatal nutrient requirement and intake of RCC cows between treatment groups are given in Table 5. There was no significant difference $(\mathrm{P}>0.05)$ between treatment groups in respect of average LW (199 and 197, $\mathrm{kg}$, respectively), metabolic LW (53 and $52 \mathrm{~kg}$, respectively) and feeding periods $(60 \mathrm{~d})$. Daily requirements of $\mathrm{CP}$ and $\mathrm{ME}$ were also similar $(\mathrm{P}>0.05)$. DM intake from roughage was similar (4.87 and $4.82 \mathrm{~kg} / \mathrm{d} ; \mathrm{P}>0.05$ ), however, it was significantly higher from concentrate $(0.56$ and $1.17 \mathrm{~kg} / \mathrm{d}$, respectively; $\mathrm{P}<0.01$ ) which resulted in significantly respectively; $\mathrm{P}<0.01)$. The $\mathrm{ME}$ and $\mathrm{CP}$ intake with reference to metabolic LW also differed significantly $(0.85$ and $1.02 \mathrm{MJ} / \mathrm{d}$, and 8.97 and $10.87 \mathrm{~g} / \mathrm{d}$, respectively; $\mathrm{P}<0.05)$. In farmers' choice diet, the intake of ME was equal to requirement (1.06 times) and that of $\mathrm{CP}$ was 1.21 times of requirement. In case of improved feeding, $\mathrm{ME}$ and $\mathrm{CP}$ intake was 1.28 and1.42 times higher than requirement. Compared to the requirements of cows in late pregnancy (43.5 $\mathrm{MJ} / \mathrm{d}$ and $519 \mathrm{~g} / \mathrm{d}$; Table 3), the requirements in early lactation was less (42 MJ/d and 388 $\mathrm{g} / \mathrm{d}$; Table 5), which might help meet nutrient requirement of cows from farmers' choice diet. 
Table 5. Nutrient requirement and intake of RCC cows during early lactation

\begin{tabular}{|c|c|c|c|c|}
\hline \multirow{2}{*}{ Parameters } & \multicolumn{2}{|c|}{ Treatments } & \multirow{2}{*}{ SEM } & \multirow{2}{*}{$\mathrm{P}$ values } \\
\hline & $\mathrm{T}_{1}$ & $\mathrm{~T}_{2}$ & & \\
\hline Average LW during lactation (kg) & 199 & 197 & 11.99 & 0.830 \\
\hline Metabolic LW $(\mathrm{kg})$ & 53 & 52 & 2.39 & 0.826 \\
\hline Postnatal feeding period (d) & 60 & 60 & - & - \\
\hline \multicolumn{5}{|l|}{ Nutrient requirements } \\
\hline $\mathrm{ME}(\mathrm{MJ} / \mathrm{d})$ & 42 & 42 & 0.96 & 0.526 \\
\hline CP (g/d) & 388 & 397 & 6.75 & 0.177 \\
\hline \multicolumn{5}{|l|}{ DM intake } \\
\hline Roughage (kg/d) & 4.87 & 4.82 & 0.12 & 0.678 \\
\hline Concentrate $(\mathrm{kg} / \mathrm{d})$ & 0.56 & 1.17 & 0.05 & $<0.001$ \\
\hline Total $(\mathrm{kg} / \mathrm{d})$ & 5.43 & 5.99 & 0.15 & 0.005 \\
\hline$\% \mathrm{LW}$ & 2.76 & 3.10 & 0.19 & 0.105 \\
\hline $\mathrm{g} / \mathrm{kgW}^{0.75} / \mathrm{d}$ & 103 & 116 & 5.45 & 0.048 \\
\hline \multicolumn{5}{|l|}{ ME intake } \\
\hline Roughage (MJ/d) & 36.43 & 35.75 & 1.57 & 0.673 \\
\hline Concentrate $(\mathrm{MJ} / \mathrm{d})$ & 8.41 & 17.17 & 1.02 & $<0.001$ \\
\hline Total $(\mathrm{MJ} / \mathrm{d})$ & 44.83 & 52.92 & 2.35 & 0.007 \\
\hline $\mathrm{MJ} / \mathrm{kgW}^{0.75} / \mathrm{d}$ & 0.85 & 1.02 & 0.06 & 0.025 \\
\hline Intake: requirement & 1.06 & 1.28 & 0.06 & 0.007 \\
\hline \multicolumn{5}{|l|}{ CP intake } \\
\hline Roughage (g/d) & 385 & 377 & 17.92 & 0.678 \\
\hline Concentrate $(\mathrm{g} / \mathrm{d})$ & 86 & 186 & 17.17 & $<0.001$ \\
\hline Total $(g / d)$ & 471 & 563 & 31.84 & 0.018 \\
\hline $\mathrm{g} / \mathrm{kgW}^{0.75} / \mathrm{d}$ & 8.97 & 10.87 & 0.72 & 0.027 \\
\hline Intake: requirement & 1.21 & 1.42 & 0.08 & 0.025 \\
\hline
\end{tabular}

RCC, Red Chittagong Cattle; LW, live weight; DM, dry matter; ME, metabolizable energy; CP, crude protein; T1, cows fed according to farmers' choice; T2, cows fed concentrate supplements to supply $25 \%$ more ME and CP than requirement (ARC, 2009); SEM, standard error of mean; $\mathrm{P}>0.05$, not significant.

Effects of postnatal feeding on milk yield and postpartum heat period

Effects of feeding on LW gain, daily milk yield and postpartum heat period of cows are presented in Table 6. Initial LW of cows after calving (196 and $188 \mathrm{~kg}$, respectively) and that after 60 days (203 and $205 \mathrm{~kg}$, respectively) were similar $(\mathrm{P}>0.05)$. However, daily gain of cows (122 and $274 \mathrm{~g} / \mathrm{d}$, respectively; $\mathrm{P}<0.05)$ and milk yield (1.97 and $2.5 \mathrm{~L} / \mathrm{d}$, respectively; $\mathrm{P}<0.05$ ) increased significantly due to improved feeding. Although postpartum heat period was not affected by diet ( 85 and $75 \mathrm{~d}$, respectively; $\mathrm{P}>0.05$ ), it was 10 days less in cows fed improved diet. Asaduzzaman et. al., (2011) reported that RCC cows during first 6 months of postnatal lose LW by $12 \mathrm{~g} / \mathrm{d}$ and produced $1.75 \mathrm{~L} / \mathrm{d}$ milk without suckling (0.8-1.2 L/d; Roy et al., 2012) when fed ME and $\mathrm{CP}$ of $27.56 \mathrm{MJ} / \mathrm{d}$ and $281 \mathrm{~g} / \mathrm{d}$ against their requirements of $39.91 \mathrm{MJ} . \mathrm{d}$ and $465 \mathrm{~g} / \mathrm{d}$, respectively. In this study, $\mathrm{ME}$ and $\mathrm{CP}$ intake of cows fed by farmers was above their requirements (1.06 and 1.21 times, respectively), and therefore, cows did not lose live weight. Significantly higher milk production in improved feeding group might be attributed to higher intake of nutrients. 
Table 6. Live weight gain, milk yield and postpartum heat period of RCC cows

\begin{tabular}{lrrrr}
\hline Parameters & \multicolumn{2}{c}{ Treatments } & SEM & P values \\
\cline { 2 - 3 } & $\mathrm{T}_{1}$ & $\mathrm{~T}_{2}$ & & \\
\hline Initial LW (kg) & 196 & 188 & 11.96 & 0.564 \\
Final LW (kg) & 203 & 205 & 12.05 & 0.880 \\
Weight gain of cows (g/day) & 122 & 274 & 20.66 & $<0.001$ \\
Daily milk yield without suckling (kg) & 1.97 & 2.50 & 0.23 & 0.046 \\
Postpartum heat period (d) & 85 & 75 & 6.41 & 0.149 \\
\hline
\end{tabular}

RCC, Red Chittagong Cattle; LW, live weight; $\mathrm{T}_{1}$, cows fed according to farmers' choice; $\mathrm{T}_{2}$, cows fed concentrate supplements to supply 25\% more ME and CP than requirement (ARC, 2009); SEM, standard error of mean; P $>0.05$, not significant.

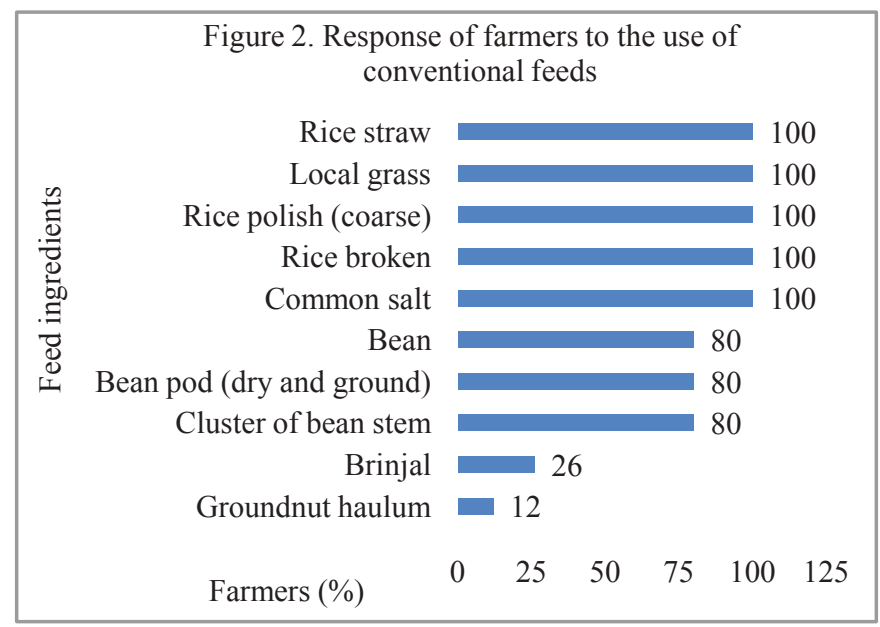

\section{On-farm feeds and feeding of RCC cows}

Responses of farmers to available feed ingredients fed to RCC cows at study area during study period are presented in Figure 2. As stated by RCC farmers, rice straw, local grass, rice polish (coarse), rice broken and common salt were fed to cows by all farmers. Bean (green), bean pod (dry and ground) and bean straw were utilized by $80 \%$ of farmers to feed RCC cows, particularly in production and harvesting seasons (February, March and April). Brinjal (26\%) and groundnut haulm $(12 \%)$ were also fed to RCC cows by some farmers during production season (February to April).

\section{Conclusion}

This study reveals that RCC cows at study areas received sufficient metabolizable energy (ME) during last 50 days of pregnancy and first 60 days of lactation $(0.98$ and 1.06 times of requirement). Crude protein $(\mathrm{CP})$ intake during these pregnant days were 0.86 parts of requirement which resulted in lower birth weight of calves (13.36 $\mathrm{kg}$ ), compared to calves from cows fed 1.33 and 1.17 times higher $\mathrm{ME}$ and $\mathrm{CP}$ than requirements $(15.12 \mathrm{~kg})$. Higher milk production along with higher live weight gain (from 1.97 to $2.50 \mathrm{~L} / \mathrm{d} ; 122$ to $274 \mathrm{~g} / \mathrm{d}$, respectively) attributed to feeding cows with 
1.28 and 1.42 times higher ME and $\mathrm{CP}$ than requirement in first two months of lactation. Therefore, it may be concluded that RCC cows in late pregnancy may be supplemented with concentrates rich in $\mathrm{CP}$ in order to produce higher birth weight of calves. In case of lactating cows, although ME and $\mathrm{CP}$ from farmers' diet is sufficient, a cost effective supplementation of concentrate for increasing milk production may be investigated by doing further research. Overall, a year round study on on-farm feeds and fodder availability, and nutrition of RCC cows with more replications in its habitats is required in order to maximize their prenatal and postnatal performances through improved nutrition.

\section{References}

Akhter, S., Huque, K. S., Jalil, M. A., and Islam, M.R. 2004. Conservation, selection and improvement of Red Chittagong Cattle through selective breeding, feeding and management. Annual Research Review workshop on 10-11 June, held in Bangladesh Livestock Research Institute, Savar, Dhaka.

AOAC, 2003. Official Methods of Analysis. (17th Edition). Association of Official Annalytical Chemists. Washington DC, USA.

ARC, 2009. Agricultural Research Council. The Nutrient Requirement of Ruminant Livestock. Commonwealth Agricultural Bureau, London, SWIY 5 AG.

Asaduzzaman, M., Alam M.R., Huque, K.S. and Sarker N.R. 2012. Study on feeding effect of productive and reproductive performances of pregnant and lactating $\mathrm{RC}$ cows in selected breeding habitat of Satkania Upazila under Chittagong district. Proceedings of Annual Research Review Workshop, 2010-2011. pp 209-213.
Bhuiyan, A.K.F.H. and Faruque, M.O. 1993. Yield and variability of milk production in the local cattle of Bangladesh.Proceeding of the BAURES Workshop.

Huque, K.S. and Sarker, N.R. 2014. Feeds and feeding of livestock in Bangladesh: performance, constraints and options forward. Bangladesh Journal of Animal Science. 43 (1): 1-10.

Huque, K.S. and Sultana, N. 2005. Review of feeding and nutrition and growth efficiency of native male cattle of Bangladesh. Research Reports of 2004-2005. Animal Production Research Division, Bangladesh Livestock Research Institute, Savar, Dhaka. pp 99.

Islam, S.S. 2010. Development of feeding system for improving productive performance of Red Chittagong cattle of Bangladesh. Ph. D. Dissertation, Department of Animal Nutrition, BAU, Mymensingh.

Kearl, L.C., 1982. Nutrient Requirements of ruminants in developing countries. International Feedstuffs Institute, Utah Agricultural Experiment Station, Utah State University, Logan, Utah 84322, USA.

Ken Ziegler, 2009. Management in the last trimester of pregnancy. Ag-Info Centre, toll-free in Alberta at 310-FARM (3276), for agricultural information, (C) 2001-2010 Government of Alberta Copyright and Disclaimer.

Mostari, M.P., Huque, K.S., Hasanat and M. S. and Gulshan, Z. 2007. Productive and reproductive efficiency of Red Chittagong Cattle under farm condition. Progress. Agric. 18(2): 109-114.

Roy, B.K., Sarker, N.R., Alam, M.K. and Huque, K.S. 2012. Study on feeding effect of shoti, wheat and soybean based milk replacers on growth performance of calves. Proceedings of Annual Research Review Workshop: 20011-2012. pp 195-208. 